ISSN: 2162-3104 Print/ ISSN: 2166-3750 Online Volume 7, Issue 2 (2017), pp. 257-269 (C) Journal of International Students http://jistudents.org/

\title{
Chinese Students' Motivations for Studying in the United States
}

Chiang-nan Chao

Niall Hegarty

John Angelidis

Victor F. Lu

St. John's University, USA

\begin{abstract}
This study examines the presence of Chinese students in U.S., and attempts to explore the reasons why so many Chinese students choose to study abroad and why the United States is their preferred destination. This population is a vital component of university life at many colleges and a much needed source of financial revenue. The results indicate that Chinese students are seeking education with a worldview and opt to break from the Chinese system of learning. This article seeks to offer academicians and university administrators a deeper understanding of the motivation of these Chinese students and contribute to the knowledge area extant on this population.
\end{abstract}

Keywords: Chinese students in U.S., International students, Mobile students.

The total number of international students in the higher education in the U.S. rose from 572,509 in $2003 / 04$ to 886,052 in $2013 / 14$, about $54.8 \%$ in the ten-year period, while the Chinese students rose from 61,765 to 274,439 during the same period, a 344\% increase, according to Open Door report (Report of Open Door, 2015). Among the competing countries for the international students, the U.S. attracted over $20 \%$ of the total international students, and it was about $4.2 \%$ of the total number students enrolled in the U.S. universities and colleges. These international students and their families spent about US\$27 billion in 2014, according to US government report (2015 Top Markets Report). By any measure, international education makes a significant contribution to the U.S. economy. In New York State 
for example, the portion of this contribution was about US\$3.2 billion, which accounts for over $10 \%$ of the national total contribution of international students. The economic impacts are not limited to the spending of these foreign students, but also their families residing in the host country (NAFSA Report). Attracting the best students from around the world has become a large and growing global export opportunity and source of competition (Zawacki-Richter \& Bedenlier, 2015; Lumby \& Foskett; 2015 Top Markets Report). Conversely, countries that see their students study abroad normally hope that these students return home and contribute to their home economy.

The U.S. has maintained its leading position for attracting international students, while China has become the largest single source of international students studying in the United States. In 2013-14, China sent 274,439 students to the United States, an increase of $17 \%$ compared with the previous year. The Chinese students make up a commanding $31 \%$ of all international students, and have accounted for about two-thirds of the increase in total international student enrollments in the U.S. since 2003. This strong growth is likely to continue, presenting important export opportunities for U.S. colleges and universities (2015 Top Markets Report; Report of Open Door, 2015). Educators and researchers seek to understand this phenomenon and identify better ways to serve this population, not as an educational strategy, but also an international trade strategy. This research, through an empirical setting intends to explore the drives of Chinese students who choose to study in the U.S. in order to provide insights and direction for educators, university administrators, and trade administrators.

\section{LITERATURE REVIEW}

Yung Wing might be the first Chinese student graduated from Yale in 1850. By 1880 there were mere 108 Chinese students studying in American universities, and almost no Chinese in European universities (The ChineseAmerican Museum of Chicago, 1880). Noticeably, China has become the largest single source of international student source for the U.S. schools in the recent years, about 31\% in 2013/14. Figure 1 shows the growth of students from China, compared with the total international students.

For thousands of years, education has been placed as a top priority by Chinese families and with China's economic reforms during the past decades leading a growth in wealth and a shrinking family size (only one child per family) sending children to international universities has become less burdensome. In the past decade, Chinese parents are tired of an education system that focuses mainly on academic scores at the expense of pupil's overall development, and many other drawbacks in China's educational system, make them seriously consider sending their children abroad for college education (Yan, 2015). 
Figure 1. Total number of Chinese vs. total international students in the U.S.

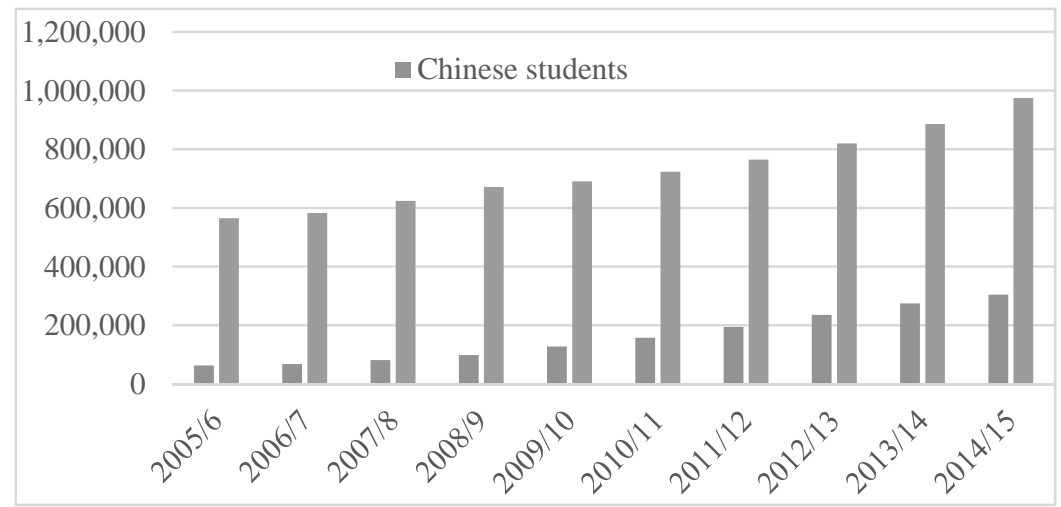

Source: Open Door, 2015.

American businesses, management knowhow, and capital have been flowing to China for the past 30 years, but it is education that reverses the tide. The benefits of studying abroad are felt both by individuals and entire nations. For these reasons educators and researchers are interested in the motivations that encourage Chinese students study in the U.S. Of all international students, about $65 \%$ of source of funding comes from students' families. Meanwhile, many U.S. universities are facing an increasingly tough financial situation with a shortage of domestic students, a decrease in corporate support, and declines in government subsidies. In such a situation, Chinese students with money to spend may fill that financial gap (WES Report, 2015; Joseph, 2012).

For Chinese students in the 2013/14 year, the top fields of study are business/management. Among all the majors, 26.5\% of Chinese students choose business and management, with knowledge these students can more easily find employments in China (Ortiz, Chang, \& Fang, 2015). Besides economic well-being, many Chinese students decide to study abroad because they believe there is a better quality education in foreign countries. The growth in Chinese students may also reflect a confluence of factors. First, more Chinese citizens are completing college and thus eligible to apply to graduate school. Second, many U.S. schools are recruiting more aggressively overseas, marketing their programs to a wider talent pool. Word of mouth then fuels the trend. Once some students attend a program, they recommend it to friends back home. Many schools have set up their gateway offices in China, i.e. Columbia University and Ohio State University. Meanwhile, new specialized master's programs appeal to students, particularly those from China, eager to delve deeper into a single subject and gain a credential to compete with the growing population of 
educated young adults, without taking much time out of the workforce (Ozturgut \& Murphy, 2009; Yan, 2015; Albrecht, Malagueno, Holland \& Sanders, 2012).

When looking into the Chinese applicants' backgrounds, many schools find some outstanding characteristics the Chinese applicants possess. First, they are China's best students who are probably aware that if they attend universities in China, they may not able to go to the best universities in the world. For example, among top 100 universities around the world, only two Chinese universities are in $39^{\text {th }}$ and $67^{\text {th }}$ places by the U.S. News and World Report (U.S. News and World Report, 2014). Unlike U.S. institutions that value candidates who present themselves as unique, their Chinese counterparts want students who excel on entrance exams that require years of rote learning and possess a strong grasp of math and science. Some critics say China's state-run education system — promoted as the hallmark of Communist meritocracy - are being overrun by bribery and cronyism. Such corruption has broadened the gulf between the privileged and non-privileged classes. Third, these young individuals are ambitious and many want to go to Ivy League schools, a symbol for those parents who raise their children successfully. Fourth, they desire to learn more about critical thinking, and very importantly, they want to be exposed to things aside from just test taking (Henze \& Zhu, 2012; Taylor, 2012; Wu, 2014; Ruiz, 2014; Soria1 \& Troisi, 2014).

Institute of International Education (IIE) published a report on motivations of the foreign students in the U.S. The report focuses on the following motivations:

1) Limited places available to study at (highly prestigious) universities in the home country;

2) Specialize in an area which is not offered in the home country;

3) Have access to specific laboratories/libraries not available/accessible in the home country;

4) Learn or improve knowledge of a foreign language;

5) Interest in foreign culture, history and landscape;

6) Get more practice-oriented education than offered in home country;

7) Possibility to build up networks/friendships in an intercultural context;

8) Improve career prospects/chances of getting a job in the home country;

9) Opportunity to develop the personality/become more independent;

10) Get a broader/more flexible education than offered in home country;

11) Experience new ways of thinking and acting in the field of study;

12) Improve chances for an international career (2015 Top Markets Report). 
The report on motivations is rather general. Other research focuses more on what graduate courses the Chinese students choose rather than why they choose United Kingdom as their destination (Zheng, 2010; Russell, Rosenthal, \& Thomson, 2010; Wu, 2014). Chao and Hegarty (2014) focuses on the Chinese students' reasons for attending colleges in the U.S. Their results indicate that Chinese students are seeking education with a worldview and opt to break from the Chinese system of learning. Their study indicates choosing to study in the U.S. may be an academic endeavor, but the reasons behind the choices are not solely for academics. Due to its preliminary nature, it is questionable for generalization of the findings. This article focuses in depth on the Chinese students' motivations for coming to the United States, so to provide some insights for educators and university administrators a better understanding of the Chinese students' motivations, therefore, serve this market segment better. This study samples a different Chinese student groups.

\section{RESEARCH METHOD}

With the focal questions in mind, this research focused on Chinese students' motives for studying in the U.S. A survey questionnaire was developed to investigate the issues related to the objectives of this study, Chinese students' motives to leave their home country and study in the U.S. Then the survey questionnaire was backwardly translated into Chinese to ensure the accuracy of the questionnaire, or in case some respondents may need a Chinese language questionnaire. However, all the respondents had an adequate grasp of the English questionnaire. The following variables were based on literature reviews.

\section{Variable Selection}

The following variables serve as motives that affect Chinese students in their decision making for studying abroad derived from the literature review.

1. Gain a new perspective on my own country;

2. Can attend a better school overseas, but not able to attend the schools I want due to China National College Entry Exam;

3. It is easy to be admitted by a foreign school;

4. It is also costly if I study in my home country;

5. My friends have gone abroad, so I would;

6. I want to be away from my country;

7. I must study abroad because my parents' wish;

8. There are more fields of studies offered by foreign schools;

9. Political easiness in programs abroad; 
10. Better living conditions, housing, eating, and environmental, i.e. clean air, etc;

11. The educational system is better overseas.

\section{Hypothesis, test of hypothesis, and sampling}

The hypotheses for this research are to find if there are any significant differences in the Chinese students' motives for choosing to study in the U.S.

$\mathrm{H}_{1}$ : There is no significant difference for Chinese students to gain a new perspective between China and the U.S.

$\mathrm{H}_{2}$ : There is no significant difference for Chinese students to attend a better school either in China or in the U.S.

$\mathrm{H}_{3}$ : There is no significant difference for Chinese students to be admitted by a foreign school either in China or in the U.S.

$\mathrm{H}_{4}$ : There is no significant difference for Chinese students to attend schools either in China or in the U.S. as far as cost is concerned.

$\mathrm{H}_{5}$ : There is no significant difference for Chinese students to attend school either in China or in the U.S. because their friends have gone.

$\mathrm{H}_{6}$ : There is no significant difference for Chinese students to attend school either in China or in the U.S. as there is no difference between the two countries.

$\mathrm{H}_{7}$ : There is no significant difference for Chinese students for where their parents wish them to study.

$\mathrm{H}_{8}$ : There is no significant difference for Chinese students to find more fields of studies either in China or in the U.S.

$\mathrm{H}_{9}$ : There is no significant difference for Chinese students to find political easiness in programs either in China or in the U.S.

$\mathrm{H}_{10}$ : There is no significant difference for Chinese students living conditions, housing, eating, and environmental, i.e. Clean air, etc. either in China or in the U.S.

$\mathrm{H}_{11}$ : There is no significant difference for Chinese students between the educational systems in China and the U.S.

Alternatively, there are significant differences in each of these hypotheses.

Due to the nature of this empirical study, the questionnaires were distributed to Chinese students in two large university campuses in the northeast America for a convenient sampling. The respondents were asked to evaluate the selected variables in a five point Likert scale, with $5=$ most important, $4=$ =important, $3=$ neutral, $2=$ not important, and $1=$ =least important.

One sample student's $t$-test is any statistical hypothesis test in which the test statistic follows a Student's $t$ distribution if the null 
hypothesis is supported. It is most commonly applied when the test statistic would follow a normal distribution if the value of a scaling term in the test statistic were known. When the scaling term is unknown and is replaced by an estimate based on the data, the test statistic (under certain conditions) follows a Student's $t$ distribution. The estimate value for testing hypotheses in this study is 3 which are either important or not important. The one sample $t$-test requires that the dependent variable follow a normal distribution. When the number of subjects in the experimental group is 30 or more, the central limit theorem shows a normal distribution can be assumed. If the number of subjects is less than 30, the researcher should plot the results and examine whether they appear to follow a normal distribution. If the distribution appears to be non-normal, and/or if the number of test cases is significantly less than 30 , then a one sample median test, which does not require a normal distribution, should be used to test the hypothesis (Hamburg, 1977; Conover, 1980; Davis and Cosenza, 1985). Five percent of the t-tests one tailed probability level was selected to signify the differences between preferences.

\section{Table 1: Backgrounds of the Respondents}

\begin{tabular}{|c|c|c|}
\hline Variables & Groups & Valid \% \\
\hline \multirow[t]{3}{*}{ 1. Age } & $<18$ & 6.4 \\
\hline & $18-35$ & 92.0 \\
\hline & $>35$ & 1.6 \\
\hline \multirow{2}{*}{ 2. gender } & Male & 56.0 \\
\hline & Female & 44.0 \\
\hline \multirow[t]{4}{*}{ 3. Family annual income } & $<\$ 30 \mathrm{k}$ & 33.9 \\
\hline & $\$ 30-50 k$ & 26.4 \\
\hline & $\$ 50-75 k$ & 13.7 \\
\hline & $>\$ 75 \mathrm{k}$ & 25.8 \\
\hline \multirow[t]{2}{*}{ 4. Education } & College & 69.6 \\
\hline & Graduate & 30.4 \\
\hline \multirow[t]{2}{*}{ 5. Marital status } & Married & 9.6 \\
\hline & Single & 90.4 \\
\hline \multirow[t]{4}{*}{ 6.Sources of financial supports } & Parent & 56.8 \\
\hline & Own saving & 5.6 \\
\hline & $\begin{array}{l}\text { Obtained scholarship or } \\
\text { GA }\end{array}$ & 22.4 \\
\hline & $\begin{array}{l}\text { Combination of various } \\
\text { sources }\end{array}$ & 15.2 \\
\hline \multirow{4}{*}{$\begin{array}{l}\text { 7. Number years studied in the } \\
\text { U.S. }\end{array}$} & $<1$ year & 13.6 \\
\hline & 1 year & 9.6 \\
\hline & 1-2 years & 16.6 \\
\hline & $>2$ years & 60.0 \\
\hline
\end{tabular}




\section{RESULTS}

Over 350 respondents were surveyed, with 128 completed responded for analyses, representing $36.5 \%$ of the total surveyed. Table 1 presents the general background information of the respondents. It is noticeable that roughly a third of the Chinese who took the survey has an annual family income over US\$75K equivalent, and most of the students were born after 1978 when one child per family policy was initiated (Healthland Time, 2013). Over $97 \%$ of the respondents took College entrance-exams and stood at the top $50 \%$, while currently, over $50 \%$ of Chinese high school graduates are able to go to college in China. In comparison, in the U.S. over $70 \%$ of the high school graduates go to college (Bureau of Labor Statistics, 2015). In another word, these respondents had alternatives for their college selections: either stay in China or go to the U.S. Table 2 presents the test results of One-Sample $t$-Test, with mean differences, $t$ values, degrees of freedom, and two tailed significances of these tests.

Table 2: One-Sample t-Test Results, test value $=3$, neutral, degree of freedom $=117-122$

\begin{tabular}{|c|c|c|c|c|}
\hline Items & Mean & $\begin{array}{l}\text { Mean } \\
\text { Dif. }\end{array}$ & $t$ & Sig. \\
\hline $\begin{array}{l}\text { 1. Gain a new perspective on my own } \\
\text { country }\end{array}$ & 3.61 & 0.61 & 4.98 & 0.000 \\
\hline $\begin{array}{l}\text { 2. Can attend a better school overseas, but } \\
\text { not able to attend the schools I want due } \\
\text { to China National College Entry } \\
\text { Examinations. }\end{array}$ & 2.99 & -0.01 & -0.06 & 0.952 \\
\hline $\begin{array}{l}\text { 3. It is easy to be admitted by a foreign } \\
\text { school. }\end{array}$ & 2.64 & -0.36 & -3.21 & 0.002 \\
\hline $\begin{array}{l}\text { 4. It is also costly if I study in my home } \\
\text { country. }\end{array}$ & 2.43 & -0.57 & -4.96 & 0.000 \\
\hline $\begin{array}{l}\text { 5. My friends have gone abroad, so I } \\
\text { would }\end{array}$ & 2.34 & -0.66 & -5.40 & 0.000 \\
\hline 6. I want to be away from my country & 2.39 & -0.61 & -4.77 & 0.000 \\
\hline $\begin{array}{l}\text { 7. I must study abroad because my } \\
\text { parents’ wish }\end{array}$ & 2.40 & -0.60 & -4.98 & 0.000 \\
\hline $\begin{array}{l}\text { 8. There are more fields of studies offered } \\
\text { by foreign schools. }\end{array}$ & 2.99 & -0.01 & -0.06 & 0.949 \\
\hline 9. Political easiness in programs abroad & 2.66 & -0.34 & -2.92 & 0.004 \\
\hline $\begin{array}{l}\text { 10.Better living conditions, housing, } \\
\text { eating, and environmental, i.e. clean air, } \\
\text { etc. }\end{array}$ & 2.84 & -0.16 & -1.36 & 0.177 \\
\hline $\begin{array}{l}\text { 11. The educational system is better } \\
\text { overseas. }\end{array}$ & 3.37 & 0.37 & 2.80 & 0.006 \\
\hline
\end{tabular}




\section{IMPLICATIONS AND RECOMMENDATIONS}

The mean differences as compared to the test value of 3 which is neutral tell the researchers how relatively important of these variables. The results show that two variables, 1 . Gain a new perspective on my own country and 11. The educational system is better overseas, show the positive mean differences, which mean the respondents view these variables more important. To supplement the survey, interviews were conducted. Many respondents indicate that Chinese Higher Education System lacks of innovation, and the students have to memorize the doctrines, rather than to find new ways of doing things. This gives credits to many US colleges that give Chinese students a worldwide view and encourage them to innovate. With regard to the other nine variables: 2. Can attend a better school overseas, but not able to attend the schools I want due to China National College Entry Exam; 3. It is easy to be admitted by a foreign school; 4. It is also costly if I study in my home country; 5. My friends have gone abroad, so I would; 6. I want to be away from my country; 7. I must study abroad because my parents' wish; 8 . There are more fields of studies offered by foreign schools; 9. Political easiness in programs abroad; 10. Better living conditions, housing, eating, and environmental, i.e. clean air, etc, the respondents express that these are less important. This would suggest to the researchers these variables are less important for the Chinese students who study in the U.S. Some respondents indicate that it is as difficult as they apply for admissions at Chinese universities, especially the top 200 universities. Many indicate that the cost of studying at Chinese universities has rapidly increased in the past years. "Catch up with Jones" is a fallacy for the Chinese students, rather than an important motive for their study aboard. These respondents indicate that there were aware that the job opportunities for foreign students were not good in North America, so the overwhelm majority need to return to China for jobs. The respondents also indicate that they come to study aboard, not subject to their parents' wishes, as they want to do at their own will. For variable 9, some respondents indicate that in the recent years, the Chinese universities ease political required courses.

The test results of One-Sample t-Test reject eight null hypotheses: 1. Gain a new perspective on my own country; 3. It is easy to be admitted by a foreign school; 4 . It is also costly if I study in my home country; 5 . My friends have gone abroad, so I would; 6. I want to be away from my country; 7. I must study abroad because my parents' wish; 9. Political easiness in programs abroad; 11 . The educational system is better overseas. In other words, these eight variables present that they are either more important or less important in Chinese students' motivations to come to the U.S. 
The test results of One-Sample t-Test accept three null hypotheses: 2. Can attend a better school overseas, but not able to attend the schools I want due to China National College Entry Exam; 8. There are more fields of studies offered by foreign schools; 10 . Better living conditions, housing, eating, and environmental, i.e. clean air, etc. In other words, the acceptances of these hypotheses recommend that the Chinese students do not view these issues differently. Many respondents indicate that the Chinese educational system is rigid, the choices of college are limited, even when the higher school students get good China National College Entry Exam scores.

What more comes through from this research is that non-academic reasons are primarily driving Chinese students to study in the U.S. Cultural aspects and desires to gain a non-Chinese world perspective emerge as primary motives for study in the U.S. This may be due to the understanding and realization by the Chinese of a global economy and the need to understand the 'internationalization' of business. These attitudes could also be considered to be consistent with attitudes of all affluent middle classes who have moved beyond daily sustenance and have achieved long term security.

\section{LIMITATIONS AND FUTURE RESEARCH}

While this study is limited by sample size and confined to Chinese students studying at only two universities in the northeast America it does provide direction and insight for future researcher to build upon. The sample size can be accepted as a good representation of the motives of Chinese students who wish to study in the U.S. as the northeast America, particularly New York State, has a larger number of Chinese students.

The Chinese students' motivations for coming to the U.S. may include more. The author took a special research tour recently in China to interview with the parents (some are grandparents) who have their children in the U.S. or plan to send their children to, indicate that they believe that higher education overseas is much better. As long as they can afford, their first choice is to let their children study overseas. Academic research on the motivations of international student populations (4\% of the total US college students), particularly Chinese students (over $1 \%$ of the total US college students) in the U.S. is limited. While much has been written in terms of their numbers and how universities accommodate Chinese students is limited. It is imperative in servicing this population that universities first need to better understand the motivations then colleges and universities in the U.S. can build programs to cater to the long term facilitation of this segment market. 
Future empirical studies may also focus the life style and living of these Chinese students in the U.S. or elsewhere, as many participate in this study, live together, and speak their own language, and it seems there is a battier between this market segment and the rest of local and international students. A further recommendation would be to look at any major differences between undergraduate and graduate Chinese students as well as differences between graduate Chinese who have completed bachelor degrees in the U.S. and those who haven't. The growing number of the Chinese students in the U.S. has raised some challenging questions for both educators and researchers. In the future, researchers will need to know more about: what are the expectations of these Chinese students when they land in the U.S.? Are their expectations met during their studies or after their studies? If their expectations are not met, what educators in the U.S. schools need to do?

\section{REFERENCES}

2015 top markets report, education--a market assessment tool for U.S. exporters, industry \& analysis (I\&A) (2015). International Trade Administration, U.S. Department of Commerce. Retrieved from http://trade.gov/topmarkets/

Albrecht, C, Malagueno, R., Holland, D., and Sanders, M. (2012). Cross cultural management: an international journal, 19(4), 433-454.

Chao, C. \& Hegarty, N. (2014). Driving forces which enthuse the continuous growth of Chinese students in U.S. colleges: a preliminary study on Chinese students' motives, Journal of Academic Administration in Higher Education, Fall, 10(2), 27-34.

The Chinese-American Museum of Chicago (1880). Comparing Japanese and Chinese students at U.S. universities.

Conover, W. J. (1980). Practical nonparametric statistics (2nd ed.). New York: John Wiley \& Sons, 213-337, 344-384).

Davis, D., \& R. M. Cosenza (1985). Business research for decision making, Boston, Kent Publishing Company.

Hamburg, M. (1977). Statistical analysis for decision making (2nd ed.). Harcourt Brace Jovanovich, Inc., New York, 219538.

Henze, J., \& Zhu, J. (2012). Current research on Chinese students studying abroad, Research in Comparative and International Education, 7(1), 90-104.

Bureau of Labor Statistics (2015). Retrieved from http://www.bls.gov/news.release/hsgec.nr0.htm;

Healthland Time (2013). Retrieved from http://healthland.time.com/2013/01/10/littleemperors/

U.S. News and world Report (2014). Retrieved from http://www.usnews.com/education/best-global-universities/rankings

Joseph, F. (2012). Overseas colleges fight for Chinese students, CNTV, October 19.

Lumby, J., \& N. Foskett (2015). Internationalization and culture in higher education, Journal of Studies in International Education, DOI: 10.1177/1741143214549978.

NAFSA Report (2014). The economic benefit of international students, \$26.8 billion contributed; 340,000 U.S. jobs supported, Economic Analysis for Academic Year 2013-2014.

Ortiz, A., Chang, L., \& Fang, Y. (2015). International student mobility trends 2015: an economic perspective, Social Science Research Network. Retrieved from 
http://wenr.wes.org/2015/02/international-student-mobility-trends-2015-aneconomic-perspective/

Ozturgut, O., \& Murphy, C. (2009). "Literature vs. practice: challenges for international students in the U.S.," International Journal of Teaching and Learning in Higher Education, 22(3), 374-385.

Report of Open Door, Institute of International Education (IIE) (2015). Retrieved from http://www.iie.org/Research-and-Publications/Open-Doors/Data/InternationalStudents/Enrollment-Trends/1948-2014

Ruiz, N. G. (2014). The Geography of Foreign Students in U.S. Higher Education: Origins and Destinations, Brookings. Retrieved from http://www.brookings.edu/research/interactives/2014/geography-of-foreignstudents\#/M10420

Russell, J., Rosenthal, D., \& Thomson, G. (2010). "The international student experience: three styles of adaptation,” Higher Education, 60(2), 235-249.

Soria1, K. M., \& J. Troisi (2014). Internationalization at Home Alternatives to Study Abroad, Journal of Studies in International Education, July 1, 18: 261-280

Taylor, A. (2012). Three Reasons China's Students are Desperate to Study in America, Business Insight.

WES Report: International trend in higher education, an Oxford Report (2015). Retrieved from

https://www.ox.ac.uk/sites/files/oxford/International\%20Trends\%20in\%20Higher \%20Education\%202015.pdf

$\mathrm{Wu}, \mathrm{Q}$. (2014). Motivations and decision-making processes of mainland Chinese students for undertaking master's programs abroad, Journal of Studies in International Education. 18(5). 426-444.

Yan, A. (2015). Why Chinese parents are sending their children abroad to study at a younger age, South China Morning Post. Retrieved from http://www.scmp.com/news/china/article/1747075/why-mainland-parents-aresending-their-children-abroad-study-younger-age?page $=$ all

Zawacki-Richter, O., \& Bedenlier, S. (2015). Internationalization of higher education and the impacts on academic faculty members, Journal of Studies in International Education, 10: 185-201.

Zheng, X. (2010). Re-interpreting silence: Chinese international students' verbal participation in U.S. universities. The International Journal of Learning, 17(5), 451464.

CHIANG-NAN CHAO, PhD, Professor of Management, earned his MBA from Lamar University, and his $\mathrm{PhD}$ in Supply Chain Management and International Business from Arizona State University. His articles, books, book chapters, conference papers, conference presentations, and case studies, etc. have published in many leading journals and conferences, i.e., Journal of World Business, the Journal of Supply Chain Management, the Journal of Education for Business, Journal of Teaching in International Business, etc. E-mail: chaoc@stjohns.edu

NIALL HEGARTY, EdD, is Assistant Professor of Management at St. John's University. His area of research covers the domain of motivation. He has published in such journals as Human Resources and Adult Learning, 
Journal of Continuing Higher Education, and Business Education and Accreditation. E-mail: hegartyn@stjohns.edu

JOHN ANGELIDIS, PhD, earned his PhD from Georgia State University. His research interests are in the area of strategic management, international business, and corporate social responsibility. He has published a great number of refereed articles in journals such as the Journal of Business Ethics, International Journal of Management, Journal of Education for Business, Journal of Global Marketing, Journal of Applied Business Research, The American Asia Review, Mid-Atlantic Journal of Business, Review of Business, and the Journal of Global Business, etc. E-mail: angelidj@stjohns.edu

VICTOR F. LU, PhD, earned his PhD degree in Operations Research from Syracuse University. His research areas are business analytics and information technology. He published a number of peer-reviewed articles in journals including Operations Research and has made numerous presentations at international and national conferences and symposia. He has authored two academic books and several book chapters, edited several conference proceedings, and served in various international and national academic organizations by holding the roles of conference chair, program chair, track chair, editor, associate editor, and reviewer. E-mail: luf@stjohns.edu

Manuscript submitted: September 28, 2015

Manuscript revised: January 30 and May 24, 2016 Accepted for publication: September 27, 2016 